\title{
PENERAPAN SASARAN KESELAMATAN PASIEN DI RUANG UGD
}

\author{
Erta Iman Jelita Harefa/181101138 \\ ertahrf08@gmail.com
}

\begin{abstract}
Abstrak
Latar belakang: Rumah sakit mempunyai berbagai unit atau bagian-bagian pelayanan kesehatan yang akan diberikan, salah satunya yaitu Unit Gawat Darurat (UGD). Pada unit ini dilaksanakan penerapan sasaran keselamatan pasien yang menunjang mutu kesehatan menjadi lebih maksimal. Tujan: Penulisan ini bertujuan untuk mengetahui dan memberi informasi tentang penerapan sasaran keselamatan pasien di ruang Unit Gawat Darurat (UGD).

Metode: Penulisan ini menggunakan metode literature review dengan pendekatan jurnal atau artikel, buku dan e-book yang relevan dan akurat serta berfokus pada penerapan sasaran keselamatan pasien di ruang UGD dengan menggunakan Google Scholar, Portal Garuda, dan Jurnal Keperawatan Indonesia.

Hasil: Berdasarkan hasil pencarian literatur terdapat beberapa sasaran keselamatan pasien yang terdiri dari: mengidentifikasi pasien dengan benar, meningkatkan komunikasi yang efektif, meningkatkan keamanan obat-obatan yang harus diwaspadai, memastikan lokasi, prosedur, dan pembedahan pasien yang benar, mengurangi risiko infeksi akibat perawatan kesehatan, dan mengurangi risiko cedera pasien akibat terjatuh.

Pembahasan: Keselamatan pasien merupakan prioritas dalam aspek pelayanan di rumah sakit dan sudah menjadi tuntutan kebutuhan dalam pelayanan kesehatan. Dalam hal ini penyelenggaraan keselamatan pasien yang dibahas disini adalah mengenai pelaksanaan sasaran keselamatan pasien khususnya disalah satu unit rumah sakit yaitu di ruang UGD. Unit Gawat Darurat (UGD) merupakan salah satu bagian dari rumah sakit yang menyediakan penanganan awal bagi pasien yang menderita sakit dan cedera yang dapat mengancam hidupnya.

Penutup: Pada keselamatan pasien khususnya pelaksanaan dan penerapan sasaran keselamatan pasien di ruang UGD dilakukan oleh dokter dari berbagai spesialisasi bersama sejumlah perawat dan juga asisten dokter. Sasaran keselamatan pasien di fokuskan pada pasien yang menjadi prioritas utama bagi rumah sakit. Sehingga fasilitas pelayanan kesehatan yang memberikan pelayanan kesehatan yang aman dan berkualitas tinggi.
\end{abstract}

Kata kunci: penerapan, sasaran keselamatan pasien, unit gawat darurat 


\section{LATAR BELAKANG}

Rumah sakit merupakan layanan jasa yang memiliki peran penting bagi kehidupan masyarakat. Rumah sakit merupakan tempat yang sangat kompleks yang terdapat berbagai macam obat, tes dan prosedur, banyak alat dengan teknologinya, berbagai jenis tenaga profesi dan non profesi yang siap memberikan pelayanan pasien 24 jam terus-menerus. Keselamatan pasien adalah suatu sistem dimana rumah sakit memberikan asuhan kepada pasien secara aman serta mencegah terjadinya cidera akibat kesalahan karena melaksanakan suatu tindakan atau tidak melaksanakan suatu tindakan yang seharusnya diambil. Dalam keselamatan pasien terdapat penyelenggaraan pembentukan sistem pelayanan yang menerapkan sasaran keselamatan pasien. Sehingga sasaran keselamatan pasien sangat penting dilaksanakan dan dilakukan dengan baik dan benar.

Sasaran keselamatan pasien merupakan suatu dukungan dalam perbaikan spesifik dalam keselamatan pasien. Sasaran keselamatan pasien adalah syarat untuk diterapkan di semua rumah sakit. Sasaran ini menyoroti bagianbagian yang bermasalah dalam pelayanan kesehatan dan menjelaskan bukti serta solusi dari konsensus berbasis bukti dan keahlian atas permasalahan. Sasaran ini sebagai pertimbangan dalam menyediakan perawatan kesehatan yang aman dan berkualitas tinggi diperlukan desain sistem yang baik dan berfokus pada solusi yang berlaku untuk keseluruhan sistem. Penyusunan sasaran ini mengacu kepada Nine Life-Saving Patient Safety Solutions dari WHO Patient Safety (2007) yang digunakan juga oleh Komite Keselamatan Pasien Rumah Sakit PERSI (KKPRS PERSI), dan dari Joint Commission International (JCI).

Secara umum rumah sakit begitu luas dan kompleks, untuk itulah penulis hanya mengkhususkan pada pelaksanaan dan penerapan sasaran keselamatan pasien di ruang UGD. Unit Gawat Darurat (UGD) merupakan suatu unit di dalam rumah sakit yang menyediakan penanganan awal bagi pasien yang menderita sakit dan cedera yang dapat mengancam kelangsungan hidupnya. Dalam hal ini unit gawat darurat juga bisa menjadi cerminan dari pelayanan rumah sakit pada umumnya yang menerima pasien dengan sifat yang membutuhkan pertolongan cepat dan tepat, sehingga jarang sekali terjadi insiden yang berhubungan dengan 
keselamatan pasien di unit gawat darurat, untuk itu para petugas diharuskan melakukan tindakan yang segera namun tetap fokus pada keselamatan pasien agar kualitas pelayanan rumah sakit tetap terjaga.

Menurut Depkes RI (2006), Unit Gawat Darurat (UGD) merupakan unit pelayanan yang sangat rentan dengan keselamatan pasien karena unit gawat darurat rumah sakit mempunyai tugas menyelenggarakan pelayanan asuhan medis dan asuhan keperawatan sementara serta pelayanan pembedahan darurat bagi pasien yang datang dengan gawat darurat medis.

\section{TUJUAN}

Tujuan penulisan ini adalah untuk mengetahui dan memberi informasi tentang penerapan sasaran keselamatan pasien di ruang Unit Gawat Darurat (UGD).

\section{METODE}

Penulisan ini menggunakan metode literature review dengan pendekatan jurnal atau artikel, buku dan e-book yang relevan dan akurat serta berfokus pada penerapan sasaran keselamatan pasien di ruang Unit Gawat Darurat (UGD). Adapun jurnal atau artikel dan e-book yang digunakan pada literature review adalah jurnal atau artikel dan e-book yang didapatkan dengan menggunakan Google Scholar, Portal Garuda, dan Jurnal Keperawatan Indonesia.

\section{HASIL}

Berdasarkan hasil pencarian literatur di dapatkan beberapa sasaran keselamatan pasien yang akan dilakukan dengan baik dan benar sebagai berikut:

\section{Mengidentifikasi Pasien Dengan} Benar

Fasilitas pelayanan kesehatan menyusun pendekatan untuk memperbaiki ketepatan identifikasi pasien. Sebab adanya kesalahan karena keliru dalam mengidentifikasi pasien terjadi di semua aspek diagnosis dan pengobatan. Kesalahan identifikasi pasien bisa terjadi pada pasien yang dalam keadaan terbius/tersedasi, mengalami disorientasi, tidak sadar, bertukar tempat tidur/kamar/lokasi di rumah sakit, adanya kelainan sensori atau akibat situasi lain. Sehingga sasaran ini bertujuan untuk melakukan dua kali pengecekan yaitu: pertama, untuk identifikasi pasien sebagai individu yang akan menerima pelayanan atau pengobatan, dan kedua untuk kesesuaian 
pelayanan atau pengobatan terhadap individu tersebut.

\section{Meningkatkan Komunikasi Efektif}

Fasilitas pelayanan kesehatan menyusun pendekatan agar komunikasi di antara para petugas pemberi perawatan semakin efektif. Komunikasi efektif adalah komunikasi yang tepat waktu, akurat, lengkap, jelas, dan yang dipahami oleh penerima sehingga akan mengurangi kesalahan dan menghasilkan peningkatan keselamatan pasien. Komunikasi dapat secara elektronik, lisan ataupun tertulis. Komunikasi yang paling mudah mengalami kesalahan adalah perintah yang diberikan secara lisan melalui telepon ataupun handphone serta komunikasi yang mudah terjadi kesalahan adalah pelaporan kembali hasil pemeriksaan kritis seperti laboratorium klinik cito melalui telepon ke unit pelayanan.

3. Meningkatan Keamanan ObatObatan Yang Harus Diwaspadai Fasilitas pelayanan kesehatan mengembangkan pendekatan untuk memperbaiki keamanan obat-obatan yang harus diwaspadai. Bila obat-obatan adalah bagian dari rencana pengobatan pasien maka penerapan menajemen harus berperan secara kritis untuk memastikan keselamatan pasien. Obatobatan yang perlu diwaspadai (highalert medications) adalah obat yang persentasinya tinggi dalam menyebabkan terjadi kesalahan/error dan kejadian sentinel (kejadian serius), obat yang beresiko tinggi menyebabkan dampak yang tidak diinginkan seperti obat-obat yang terlihat mirip dan kedengarannya mirip (Nama Obat Rupa dan Ucapan Mirip/NORUM atau Look Alike Soun Alike/LASA). Daftar obatobatan yang sangat perlu diwaspadai tersedia di WHO.

4. Memastikan Lokasi Pembedahan Yang Benar, Prosedur Yang Benar, Pembedahan Pada Pasien Yang Benar Fasilitas pelayanan kesehatan mengembangkan suatu pendekatan untuk memastikan tepat lokasi, tepat prosedur, dan tepat pasien operasi. Pada salah-lokasi, salah-prosedur, salahpasien operasi adalah kejadian yang mengkhawatirkan dan biasa terjadi di fasilitas pelayanan kesehatan. Kesalahan ini adalah akibat dari komunikasi yang tidak efektif atau tidak adekuat antara anggota tim bedah, kurang/tidak melibatkan pasien di dalam penandaan lokasi, dan tidak ada prosedur untuk memverifikasi lokasi operasi. Di samping itu juga asesmen pasien yang 
tidak adekuat, penelaahan ulang cacatan medis tidak adekuat, budaya yang tidak mendukung komunikasi terbuka antar anggota tim bedah, permasalahan yang berhubungan resep yang tidak terbaca dan pemakaian singkatan adalah faktorfaktor kontribusi yang sering terjadi.

5. Mengurangi Risiko Infeksi Akibat Perawatan Kesehatan

Fasilitas pelayanan kesehatan mengembangkan suatu pendekatan untuk mengurangi risiko infeksi yang terkait pelayanan kesehatan. Pencegahan dan pengendalian infeksi merupakan tantangan praktisi dalam kebanyakan tatanan pelayanan kesehatan dan peningkatan biaya untuk mengatasi infeksi yang berhubungan dengan pelayanan kesehatan merupakan keprihatinan besar bagi pasien maupun para profesional pelayanan kesehatan. Infeksi umumnya dijumpai dalam semua bentuk pelayanan kesehatan termasuk infeksi saluran kemih-terkait kateter, infeksi aliran darah, dan pneumonia. Pusat dari eliminasi infeksi ini maupun infeksi-infeksi lain adalah cuci tangan yang tepat.

6. Mengurangi Risiko Cedera Pasien Akibat Terjatuh

Fasilitas pelayanan kesehatan mengembangkan suatu pendekatan untuk mengurangi risiko pasien dari cedera karena jatuh. Dalam hal ini, jumlah kasus jatuh cukup bermakna sebagai penyebab cedera bagi pasien rawat inap. Dalam konteks populasi/ masyarakat yang dilayani, pelayanan yang diberikan dan fasilitasnya, serta pelayanan kesehatan perlu mengevaluasi risiko pasien jatuh dan mengambil tindakan untuk mengurangi risiko cedera bila sampai jatuh. Evaluasi bisa termasuk riwayat jatuh, obat dan telaah terhadap konsumsi alkohol, gaya jalan dan keseimbangan, serta alat bantu berjalan yang digunakan oleh pasien. Program ini harus diterapkan rumah sakit.

\section{PEMBAHASAN}

Keselamatan pasien merupakan prioritas dalam aspek pelayanan di rumah sakit dan sudah menjadi tuntutan kebutuhan dalam pelayanan kesehatan. Keselamatan pasien (patient safety) adalah permasalahan yang sangat penting dalam setiap pelayanan kesehatan sehingga keselamatan merupakan tanggungjawab dari pemberi jasa pelayanan kesehatan terutama pelayanan keperawatan di setiap unit perawatan baik akut maupun kronis harus berfokus pada keselamatan pasien 
baik dalam tatanan rumah sakit. keselamatan pasien mempunyai penyelenggaraan yang dilakukan melalui pembentukan sistem pelayanan yang menerapkan: standar keselamatan pasien, sasaran keselamatan pasien, dan langkah menuju keselamatan pasien. Dalam hal ini penyelenggaraan keselamatan pasien yang dibahas disini adalah mengenai pelaksanaan sasaran keselamatan pasien khususnya disalah satu unit rumah sakit yaitu di ruang UGD. Unit Gawat Darurat (UGD) merupakan salah satu bagian dari rumah sakit yang menyediakan penanganan awal bagi pasien yang menderita sakit dan cedera yang dapat mengancam hidupnya.

Berdasarkan hasil pencarian literatur dan hasil yang telah dibahas bahwa pelaksanaan sasaran keselamatan pasien di ruang UGD sudah terlaksana secara teratur dan melakukan semua bagianbagian dari sasaran keselamatan pasien dengan benar dan baik. Sehingga hal ini tetap menjaga dan meningkatkan mutu pelayanan kesehatan di rumah sakit.

\section{PENUTUP}

Pada keselamatan pasien khususnya pelaksanaan dan penerapan sasaran keselamatan pasien di ruang UGD dilakukan oleh dokter dari berbagai spesialisasi bersama sejumlah perawat dan juga asisten dokter. Sasaran keselamatan ini sudah dilaksanakan secara teratur. Hal ini memberikan kemajuan dan juga peningkatan dalam mutu pelayanan kesehatan menjadi lebih maksimal.

Sasaran keselamatan pasien di fokuskan pada pasien yang menjadi prioritas utama bagi rumah sakit. Sehingga fasilitas pelayanan kesehatan yang memberikan pelayanan kesehatan yang aman dan berkualitas tinggi.

\section{REFERENSI}

Cahyawening, Putri T., Intiasari, A. D., Budi, A. (2018). Implementasi Clinical Risk Management (CRM) di Unit Gawat Darurat RSUD Banyumas Tahun 2018. Jurnal Kesmas Indonesia, Vol. 10, No. 2.

Departemen Kesehatan RI. (2006). Sistem Penanggulangan Gawat Darurat Terpadu. Jakarta: Depkes RI.

Departemen Kesehatan RI. (2008). Panduan Nasional Keselamatan 
Pasien Rumah Sakit (Patient

Safety). Jakarta: Depkes RI.

Departemen Kesehatan RI. (2008).

Upaya Peningkatan Mutu

Pelayanan Rumah Sakit. Jakarta:

Depkes RI.

Harus, Bernadeta D., Sutriningsih, A. (2015). Pengetahuan Perawat Tentang Keselamatan Pasien

Dengan Pelaksanaan Prosedur

Keselamatan Pasien Rumah

Sakit (KPRS) di Rumah Sakit

Panti Waluya Sawahan Malang.

Jurnal CARE, Vol. 3, No. 1.

Ismainar, Hetty. (2015). Keselamatan

Pasien di Rumah Sakit.

Yogyakarta: Deepublish.

Kamil, H. (2010). Patient Safety. Idea Nursing Journal, 1-8.

Keles, Angelia W., Kandou, G. D., Tilaar, Ch. R. (2015). Analisis

Pelaksanaan Standar Sasaran

Keselamatan Pasien di Unit

Gawat Darurat RSUD Dr. Sam

Ratulangi Tondano Sesuai

Dengan Akreditasi Rumah Sakit

Versi 2012. JIKMU, Vol. 5, No.

2.

Kusumaningrum, Bintari R., Winarni, I.,

Setyoadi,

Kumboyono,

Ratnawati, R. (2013).

Pengalaman Perawat Unit
Gawat Darurat (UGD)

Puskesmas Dalam Merawat

Korban Kecelakaan Lalu Lintas.

Jurnal Ilmu Keperawatan, Vol. 1, No. 2.

Machmud, R. (2008). Manajemen Mutu Pelayanan Kesehatan. Jurnal Kesehatan Masyarakat, 186-190. Permenkes RI. (2011). Peraturan Menteri Kesehatan Republik Indonesia Nomor 1691/Menkes/Per/VIII/2011

Tentang Keselamatan Pasien Rumah Sakit. Jakarta: Depkes RI.

Permenkes RI. (2017). Peraturan Menteri Kesehatan Republik Indonesia Nomor 11 Tahun 2017 Tentang Keselamatan Pasien. Jakarta: Depkes RI.

Simamora, R. H. (2019). Buku Ajar Pelaksanaan Identifikasi Pasien. Uwais Inspirasi Indonesia.

Simamora, R. H. (2019). Documentation of Patient Identification Into The Electronic System to Improve The Quality of Nursing Services. International Journal of Scientific \& Technology Research.

Simamora, R. H. (2019). The Influence of Training Handover Based SBAR Communication for 
Improving Patients Safety.

Indian Journal of Public Health

Research \& Development.

Tutiany, Lindawati, Krisanti P. (2017).

Bahan Ajar Keperawatan:

Manajemen Keselamatan

Pasien. Jakarta: Kemenkes RI.

Wardhani, Viera. (2017). Buku Ajar Manajemen Keselamatan

Pasien. Malang: UB Press. 